\title{
MNC Organizational Form and Subsidiary Motivation Problems Controlling Intervention Hazards in the Network MNC
}

Foss, Kirsten; Foss, Nicolai J.; Nell, Phillip C.

Document Version

Final published version

Publication date:

2011

License

CC BY-NC-ND

Citation for published version (APA):

Foss, K., Foss, N. J., \& Nell, P. C. (2011). MNC Organizational Form and Subsidiary Motivation Problems:

Controlling Intervention Hazards in the Network MNC. Institut for Strategic Management and Globalization. SMG Working Paper No. 13/2011

Link to publication in CBS Research Portal

\section{General rights}

Copyright and moral rights for the publications made accessible in the public portal are retained by the authors and/or other copyright owners and it is a condition of accessing publications that users recognise and abide by the legal requirements associated with these rights.

Take down policy

If you believe that this document breaches copyright please contact us (research.lib@cbs.dk) providing details, and we will remove access to the work immediately and investigate your claim. 
MNC Organizational Form and Subsidiary Motivation Problems:

Controlling Intervention Hazards in the Network MNC

\author{
Kirsten Foss \\ Nicolai J. Foss \\ Phillip C. Nell \\ SMG WP 13/2011
}

December, 2011 
SMG Working Paper No. 13/2011

December, 2011

ISBN: 978-87-91815-75-1

Department of Strategic Management and Globalization Copenhagen Business School

Kilen, Kilevej 14A

2000 Frederiksberg

Denmark

www.cbs.dk/smg 
MNC ORGANIZATIONAL FORM AND SUBSIDIARY MOTIVATION PROBLEMS: CONTROLLING INTERVENTION HAZARDS IN THE NETWORK MNC

\author{
Kirsten Foss, Nicolai J. Foss \\ Department of Strategy and Management \\ Norwegian School of Economics and Business Administration \\ Breiviksveien 40; N-5045; Bergen; Norway \\ Department of Strategic Management and Globalization \\ Copenhagen Business School \\ Kilevej 14, $2^{\text {ndt }}$ floor; 2000 Frederiksberg; Denmark \\ njf.smg@cbs.dk \\ Phillip C. Nell \\ Department of Strategic Management and Globalization \\ Copenhagen Business School \\ Kilevej 14, $2^{\text {ndt }}$ floor; 2000 Frederiksberg; Denmark \\ pcn.smg@cbs.dk
}

06. December, 2011

\title{
Acknowledgment
}

We thank (without implicating) Ulf Andersson and Stefan Linder for discussion of key points in this paper, and two reviewers for stimulating comments on a previous version of the paper. The authors contributed equally to this research.

Keywords: The network MNC, headquarters, managerial opportunism, psychological contracts, procedural justice.

JEL Codes: D23, F23, L14, M14 
MNC ORGANIZATIONAL FORM AND SUBSIDIARY MOTIVATION PROBLEMS: CONTROLLING INTERVENTION HAZARDS IN THE NETWORK MNC

\begin{abstract}
The MNC literature treats the (parent) HQ as entirely benevolent with respect to their perceived and actual intentions when they intervene at lower levels of the MNC. However, HQ may intervene in subsidiaries in ways that demotivate subsidiary employees and managers (and therefore harm value-creation). This may happen even if such intervention is benevolent in its intentions. We argue that the movement away from more traditional hierarchical forms of the MNC and towards network MNCs placed in more dynamic environments gives rise to more occasions for potentially harmful intervention by HQ. Network MNCs should therefore be particularly careful to anticipate and take precautions against "intervention hazards." Following earlier research, we point to the role of normative integration and procedural justice, but argue that they also serve to control harmful HQ intervention (and not just subsidiary opportunism).
\end{abstract}

Keywords: The network MNC, MNC HQ, managerial intervention and opportunism, normative integration, procedural justice. 


\section{INTRODUCTION}

In the extant literature on the multinational corporation (MNC), the parent headquarters (HQ) plays a wholly benevolent role. ${ }^{1}$ It is recognized that the HQ may be ill-informed, for example because of information overload (Egelhoff, 1991, 2010), radical uncertainty (Forsgren \& Holm, 2010), or sheer ignorance (Forsgren, Holm \& Johanson, 2005), and may suffer from “bounded reliability” (Verbeke \& Greidanus, 2009). These problems may give rise to managerial errors in decision-making, such as failing to recognize synergies between lower-level units, implementing badly designed reward systems, and cannibalizing product lines. Such errors harm value-creation at the level of subsidiaries and the MNC.

However, there is little or no questioning in the literature that the HQ is somehow motivated to add value to the overall MNC network and is perceived as such by other units in the MNC. ${ }^{2}$ Thus, the literature specifies how the HQ engages in strategic planning, assists the subsidiaries with various support functions, transfers useful knowledge to the subsidiaries, orchestrates lateral knowledge transfers across the MNC network, and reduces latent or manifest incentive problems by deploying means of organizational control (e.g. Ghoshal \& Bartlett, 1989; Gupta \& Govindarajan, 2000; O’Donnell, 2000; Doz \& Prahalad, 1984). Furthermore, the HQ is supposed to differentiate its coordination and control mechanisms according to the specific subsidiary situation, while not sacrificing firm-level performance for sub-unit gains (Nohria \& Ghoshal 1994). Such acts of intervention, either directly or by creating organizational infrastructure, add to MNC-wide value

\footnotetext{
${ }^{1}$ We follow the usual understanding of the HQ as the entity at the top of a firm that assumes responsibility for functions like strategic planning, corporate communications, tax, legal, marketing, finance, human resources and information technology. HQ includes the CEO and other members of the top-management team, support functions for topmanagement team, corporate policy making functions, and corporate services of all kinds.

${ }^{2}$ To illustrate, none of the contributors to a recent edited volume titled Managing the Contemporary Multinational: The Role of HQ (Andersson \& Holm, 2010) question the assumption of fundamentally benevolent HQ, although Benito and Tomassen (2010) implicitly raise the conceptual possibility of opportunistic HQs in their discussion of bonding costs between the HQ and the subsidiaries. Similarly, none of the contributors to a recent special issue (Management International Review, 50: 4) on the topic of "How do MNC Headquarters Add Value?" question the benevolence assumption.
} 
creation, save for those instances where errors turn out (retrospectively) to have been made. If they have any direct impact on subsidiary motivation, it is a positive one.

We argue that this assumption of general (perceived) HQ benevolence is one that needs substantial modification, particularly because of the emergence and diffusion of more decentralized and less formalized "network forms" of the MNC that have emerged in response to increased dynamism and heterogeneity in MNC environments. We argue that HQ may intervene in subsidiaries in a manner that demotivates subsidiary employees and managers, even if such intervention is entirely benevolent in its intentions. Interventions by HQ often amount to breaking with existing routines and procedures_-which often function as truces (Nelson \& Winter, 1982)—, overriding existing instructions of employees or subsidiaries. In those MNCs where subsidiaries enjoy considerable autonomy, HQ intervention may amount to overruling decisions that units have made on the basis of decision rights that have been delegated to them (see Hofstede [1967] for the case of budgets). Or, intervention may consist of directly reducing the level of autonomy of the subsidiary. Motivational problems with far-reaching and negative implications for productivity, extra-role behaviors, and, by consequence, subsidiary- and MNC-level value creation can arise when subsidiary managers and employees perceive such intervention as ill-intentioned or simply as meddling. In fact, they may overwhelm any positive effects the intervention may otherwise have. In analogy to the notion of "contractual hazards" in the economics of the firm (Williamson, 1985) we refer to managerial interventions that harm motivation and have negative implications for value creation an "intervention hazard."3

We argue that the movement away from more traditional hierarchical forms of the MNC and towards network-based forms gives rise to more occasions for potentially harmful HQ intervention. Such forms are typically based in uncertain environments that may motivate intervention by HQ

\footnotetext{
${ }^{3}$ Note that this construct includes both those situations where net value creation is harmed and those where it is only gross value creation that is harmed (i.e., the intervention harms motivation but still creates net value). Presumably, it is desirable to avoid harming motivation in any case.
} 
(Williamson, 1991). Any firm faces the problem of promoting beneficial HQ intervention, while constraining intervention hazards. However, we argue that the problem is particularly pressing to network MNCs; therefore, they should be particularly careful to anticipate and take precautions against intervention hazards.

We thus contribute to answering the question that Kim and Mauborgne (1993) described as one of the most compelling ones in international management: How can MNCs motivate their subunits? ${ }^{4}$ Although almost two decades have passed since this issue was raised as a crucial one; and yet, research on it still remains scarce. We relate to Kim and Mauborgne (1993) and Nohria and Ghoshal (1994) by invoking normative integration and procedural justice as mechanisms that may reduce the incidence and severity of intervention hazards. However, we turn their argument around: While these two constructs have been treated as means to manage and control subsidiaries, we argue that they might serve as means to control the HQ. Note the counterfactual nature of our argument: Because network MNCs are more likely to be plagued by intervention hazards than more hierarchical MNCs, they are also more likely to make use of normative integration and procedural justice to control latent intervention hazards.

\section{THE NETWORK MNC AND THE THEORY OF THE FIRM}

\section{Research Framework}

Our overall research framework is depicted in Figure 1. We seek to link a specific organizational form of the MNC, the network form, to the incidence of intervention hazards. Selective intervention influences the motivation of MNC subunits, which in turn has performance consequences. In the following we work our way from the left towards the right in the figure,

\footnotetext{
${ }^{4}$ Throughout our analysis we operate with two assumptions which we deem necessary for reasons of simplicity and theoretical rigor. First, we assume that the MNC operates only with two hierarchical layers, that is, with the corporate HQ and the subsidiary level. Second, we assume that the motivation of a subsidiary is to a large extent represented by the motivation of the subsidiary top manager. This is appropriate based on the idea that the subsidiary top manager is probably one of the key contact persons for the corporate HQ while she/he also influences to a large extent how the rest of the subsidiary perceives, deals with, and implements corporate directives.
} 
describing each key construct in the process and explaining the causal links between them. As indicated in the figure we draw on three distinct bodies of literature. First, our overall conceptualization of the MNC in its various forms is informed by the MNC literature (e.g., Hedlund, 1986; Ghoshal \& Bartlett, 1989; Gupta \& Govindarajan, 2000; Egelhoff, 2010). We argue, however, that this literature is characterized by a research gap; specifically it fails to systematically address the link between HQ interventions and subsidiary motivations and the consequences of this. Economic theorists of the firm highlight how opportunism may sometimes be exercised by managers (Dow, 1987; Kreps, 1990; Baker, Gibbons \& Murphy, 1999), harming productivity and value creation (Williamson, 1985; Kreps, 1990; Miller, 1992; Aghion \& Tirole, 1997; Baker, Gibbons \& Murphy, 1999; Foss, 2003). Thus, like Egelhoff (2010) we draw on the economics of the firm for the purpose of understanding the role of the HQ, but go beyond the unidimensional treatment of motivation in this research stream. We provide a richer view of motivation and how it is influenced by management action. Specifically, we draw on the literature in the organizational behavior field that explores the negative motivational consequences of such intervention in the context of employment relations (e.g. Brockner, Tyler, Cooper \& Schneider, 1992; Coyle-Shapiro \& Kessler, 2000).

\section{Insert Figure 1 Here}

\section{New Network Forms of the MNC}

MNC structures have traditionally been analyzed as formal hierarchical structures (e.g. Stopford \& Wells, 1972, Daniels, Pitts \& Tretter, 1984; Gates \& Egelhoff, 1986). In the last decades, new network-like forms of MNCs have been discussed intensively and have been positioned as alternatives to the traditional hierarchical model (Malnight, 1996). Network structures 
cover a variety of conceptualizations in the MNC literature, such as the heterarchy (Hedlund, 1986), the multifocal firm (Prahalad \& Doz, 1987), the inter-organizational network (Ghoshal \& Bartlett, 1990), the transnational firm (Bartlett \& Ghoshal, 1989), or the geocentric model (Perlmutter, 1969). No single clear definition of what a MNC network structure really is exists. However, the above concepts share the assumption that hierarchical and highly formalized organizational structures with a high degree of specialization and decision-making power concentrated on the top are less suited for meeting the organizational and management challenges of learning organizations in turbulent environments. In contrast, a high degree of decentralization, relatively little formalization, lateral communication and knowledge transfer between loosely coupled units, and a variety of "integrating mechanisms," such as normative integration and project teams (O'Donnell, 2000) complement traditional authority mechanisms in coping with such challenges (e.g. Malnight, 1996). ${ }^{5}$ Drawing on the above contributions, we proffer the following definition:

Definition: A network MNC strongly delegates decision rights to subsidiaries, while retaining some decision-rights at the $H Q$. It is often characterized by a low degree of formalization, extensive lateral communication and knowledge transfer. Its subsidiaries are often resource-rich, hence powerful. It is a change-oriented organization situated in high-dynamism environments in which local adaptation as well as integration pressures coexist.

\section{The HQ in the Network MNC}

While the network model has arguably been prompted by dynamic environments, key elements of hierarchies, such as centralized decision-making for specific activities (e.g., overall strategy making, branding issues, organizational design decisions, etc.) remain. In other words, there is still an important role for the HQ in the modern network MNC. However, as Egelhoff

\footnotetext{
${ }^{5}$ A parallel trend in organization theory similarly argues that traditional hierarchies increasingly give way to "internal hybrids" that are better suited to deal with the challenges of dynamic contexts (Zenger \& Hesterly, 1997).
} 
(2010: 404) points out, the literature on the network MNC “... has tended to ignore both the general role of hierarchy and the more specific role of a parent HQ in MNCs." The literature on the network MNC places relatively more emphasis on the subsidiary level, notably the role that subsidiaries play within the MNC (Birkinshaw \& Pedersen, 2009). Thus, research has examined the "mandates" of subsidiaries, what makes for an "entrepreneurial" subsidiary, lateral knowledge flows between subsidiaries, and so on (e.g., Birkinshaw, 1997a, 2001). In fact, in this literature there has been a tendency to regard the HQ as merely one unit among many others that does not necessarily have neither the knowledge nor the power to effectively exercise authority over subsidiaries (Andersson et al., 2007; Doz et al., 2001; Tallman \& Koza, 2010). This tendency may have contributed to the literature being less forthcoming about the role of the HQ in a network MNC.

\section{Authority in the Theory of the Firm}

We are uncomfortable with this tendency. Within the MNC, as in any firm, the HQ is the holder of ultimate decision rights, or authority (Baker, Gibbons \& Murphy, 1999). Specifically, it holds rights of fiat relative to other MNC units, notably the subsidiaries. A key theme in the theory of the firm since Coase (1937) is that the exercise of managerial fiat, or authority, in response to changes in the environment provides a reason why firms exist (Casson, 1994; Williamson 1996). In Coase (1937; see also Simon, 1951) authority means that the manager (or, in the present context, the HQ) picks a well-defined action from the employee's (or, subsidiary's) action set and instructs him to carry out this action. Obviously, this presupposes that the manager (HQ) is more informed than the employee (subsidiary) about which action should rationally be chosen, and that the manager (HQ) has full knowledge of the employee's (subsidiary's) action set. Both assumptions are clearly unrealistic, given the increasing importance of geographically distant subsidiary units that are included in the MNC portfolio, often for exactly the reason that they possess knowledge advantages relative to the rest of the MNC. 
However, Simon (1991: 31) points out authority may be understood more broadly, namely as a command that takes the form of a result to be produced, a principle to be applied, or goal constraints, so that "[o]nly the end goal has been supplied by the command, and not the method of reaching it." However, even this is arguably too narrow. Usually, some aspects of "the method of reaching" an end goal are specified, so that employees are seldom granted full discretion. Indeed, a function of authority is placing restrictions on the decision rights that are granted to employees with respect to how they reach an end goal (Holmström, 1999). This function of authority is exercised in order to avoid costs associated with unwanted externalities that may arise from employee discretion, such as moral hazard or coordination failures (e.g., scheduling problems, duplicative efforts, cannibalization of product markets, etc.). It is this kind of authority that a MNC HQ usually seeks to exercise relative to subsidiaries.

\section{Delegation of Decision Rights}

Network forms of the MNC are ostensibly oriented towards "innovation, renewal, and change" (Hedlund \& Ridderstråle, 1996: 329), and are adopted in environments calling for such a dynamic stance. The reason that the MNC network form arguably fits dynamic and diverse environments is mainly that it goes much further than traditional hierarchical MNC forms with respect to delegating decision rights, that is, the right to make decisions over MNC resources. MNCs delegate decision rights for many reasons.

A subsidiary may be better informed than the HQ with respect to, for example, the design and execution of competitive strategies in local markets, dealing with authorities, etc. Often such superior knowledge is costly to communicate to the HQ (Casson, 1994), and delegation reduces the costs of processing and transmitting information from MNC units to the HQ (Egelhoff, 1991; Nobel \& Birkinshaw, 1998; Wolf \& Egelhoff, 2002). Early work on the network MNC argues that higher complexity in the subsidiary environment makes it impossible for the HQ to keep decision-making 
rights as the HQ lacks the knowledge required for the decision at hand (e.g., Nohria \& Ghoshal, 1994). Learning or entrepreneurship may also be a reason of delegation, because delegation may lead to the discovery of new knowledge that would not be discovered in the absence of delegation (cf. Foss, Foss \& Klein, 2007). For example, a subsidiary might find new ways of approaching and mastering market challenges, such as overcoming competitors' moves (e.g., Birkinshaw, 1997b, 2001). Motivational reasons have also been highlighted (Deci \& Ryan, 2000). Thus, delegation of discretion to subsidiary managers may raise perceived self-determination and thus strengthen autonomous motivation, including intrinsic motivation (Osterloh \& Frey, 2000; Gagnè \& Deci, 2005). An increase in creativity in the pursuit of goals may follow; expert knowledge is better utilized, and learning is fostered. In contrast, decreasing the level of delegated discretion reduces perceived self-determination and crowds out autonomous motivation. ${ }^{6}$

\section{Managing Delegation}

Even in a network MNC, the HQ is still needed to define the decision rights of subsidiaries (i.e., give them "mandates"), to build an information infrastructure, set up reward systems, coordinate subsidiary actions (if lateral consultation cannot take care of this), and engage in overall strategy making (e.g., Egelhoff, 2010). Therefore, there are limits to decentralization and the organizational design issue is deciding on the optimal choice between centralization and decentralization (e.g., Wolf, 1997).

An important HQ function is to reduce costs from delegation. These are the well known agency costs (O'Donnell, 2000), but also coordination failures that may arise because of the decentralization that delegations implies (Egelhoff, 2010). Given that there are costs as well as benefits for MNCs of delegating discretion to subsidiaries, HQ confront a trade-off with respect to

\footnotetext{
${ }^{6}$ Such reasoning is the basis in some MNC literature for measuring subsidiary motivation with the proxy of subsidiary autonomy (e.g., O’Donnell, 2000; Gupta \& Govindarajan, 2000).
} 
the choice of delegation (Jensen \& Meckling, 1992). Under norms of rationality, MNCs seek to implement the optimal trade-off. This is manifest in the specific organizational form adopted by the $\mathrm{MNC}$, as well as the instruments of organizational control that are deployed to support the optimal trade-off. Thus, defining the organizational structure of the MNC implies defining the decision rights of subsidiaries. To control the information and incentive issues that delegation gives rise to, MNCs implement management information and reward systems (Jensen \& Meckling, 1992; Egelhoff, 2010).

Once implemented, an optimal trade-off can persist as long as contingencies (technology, tastes, competitive conditions, etc.) remain stable. When they change, the optimum trade-off also changes. Changes in contingencies are likely to change the optimum degree of delegation. For example, research has demonstrated that the discretion levels of foreign $R \& D$ units change when the local environment changes (e.g., Asakawa 2001). Birkinshaw and Hood (1998) propose that local environmental dynamism increases the likelihood of parent- or subsidiary-driven charter change for the subsidiary, that is, the scope of activities for which the subsidiary has responsibility and discretion. Arguably, such phenomena are driven by perceived benefits of changing discretion being larger than the perceived costs. However, in order to fully understand the benefits and costs of changing the decision rights that are granted to subsidiaries, we submit that it is necessary to consider motivational and incentive considerations more fully. Specifically, we need to consider intervention hazards.

\section{Motivation and Incentive Problems}

Motivation and incentive problems have often been discussed in the MNC literature. Most contributions investigate the type of incentives used by HQs and their antecedents and consequences. For example, Gupta and Govindarajan (2000) discuss the motivational dispositions of knowledge receivers and transmitters within MNCs. They find that incentives based on MNC 
network gains do not influence knowledge outflows but only inflows from the HQ. ${ }^{7}$ They also regard subsidiary autonomy as one element of the subsidiary's motivational disposition and they find that such autonomy has a negative effect on inflows from the MNC corporate HQ. Minbaeva et al. (2003) find support for the idea that certain incentive types drive subsidiary employee motivation which in turn positively moderates the relationship between employee ability and knowledge transfer. Mudambi and Navarra (2004) report that subsidiaries with high bargaining power tend to appropriate high levels of rents. They conclude that while subsidiary autonomy might be formally conferred by the HQ, it is also (informally) driven by the subsidiary's internal bargaining power vis-à-vis the HQ. They suggest that strong organizational culture and mechanisms that may foster intrinsic motivation at the level of subsidiary employees may serve to constrain such rent-seeking.

Overall, these papers have in common that they equate decentralized decision-making with subsidiary motivation, and that they address problems of moral hazard, with the HQ in the position of the principal and subsidiaries in the positions of agents. There is, however, no mention of the possibility that the HQ may act opportunistically relative to subsidiaries (or, at least, be perceived of acting opportunistically).

The possibility of management opportunism has been discussed by Williamson $(1985,1996)$ under the heading of "selective intervention." As Williamson clarifies, selective intervention by a firm's top-management may break commitments, and be harmful for this reason. The problem is that the option to intervene "... can be exercised both for good cause (to support expected net gains) and for bad (to support the subgoals of the intervenor)" (Williamson 1996: 150-151), and it may be difficult to verify the nature of the cause. Williamson casts this in terms of a credible commitment when he notes that there may be problems of “... credibly [promising] to respect autonomy save for

\footnotetext{
${ }^{7}$ The scope of incentives is defined as a continuum between incentives based on subsidiary-specific performance vs. incentives based on firm-level performance.
} 
those cases where expected net gains to intervention can be projected" (Williamson, 1993: 104). A further problem is that even if intervention is "exercised for good cause," levels lower in the organization may still believe that the intervention is undertaken to "support the subgoals of the intervenor." Thus, cross-level dynamics of intentions and beliefs seem essential to understanding the motivational impact of HQ intervention.

\section{A Taxonomy of Headquarters Intervention}

These cross-level dynamics can be mapped with a $2 \times 2$ matrix that juxtaposes the HQ's intentions (intervention for good and bad cause) and the subsidiaries' perceptions (correct perception of HQ intentions and incorrect perceptions); see Figure 2.

\section{Insert Figure 2 Here}

Cell I represents the extant MNC literature in which it is assumed that the HQ is benevolent and succeeds in making it credible that its actions are undertaken for good cause. Cell IV represents a situation in which the HQ acts opportunistically, and is perceived as such. In Cell III the HQ intervenes because of real net gains to be achieved by the intervention, but the subsidiary does not perceive it as such. ${ }^{8}$ In Cell II the HQ intervenes for bad cause, but this is not perceived by subsidiary managers. Cell II and III may represent unstable situations, because the subsidiaries may eventually find out that the HQs were intervening for bad (good) causes. Note, that of all cells, only Cell I creates unambiguously positive effects on MNC performance. Hence, Cells II, III, and IV represent situations of what we call "intervention hazards".

\section{Why Harmful Intervention?}

\footnotetext{
8 This suggests that there may be instances where, although the HQ is "in the know," they should not intervene because this is harmful to subsidiary motivation.
} 
These situations represent hazards because they have the potential of harming subsidiary motivation, with harmful repercussions for subsidiary and eventually MNC level value creation. It may be asked why HQ would intervene such that motivation is harmed in subsidiaries and/or value is destroyed (Cells II-IV). The following reasons may be offered. First, HQ may derive a private benefit (in whatever form) from managerial intervention that destroys value. For example, to the extent that subsidiary autonomy is associated with slack, HQ may reduce autonomy and the associated slack because this makes them look good in the eyes of owners of the MNC. This may work when the negative consequences for value creation only arrive after a significant delay, or if it is very difficult to trace these consequences to the managers' behavior. A second reason relates to the time inconsistency problem (Kydland \& Prescott, 1977). In the context of delegation, such behavior may consist in, first, delegating substantial autonomy to subsidiaries. When subsidiaries, enthused about their new extended discretion, come up with value-increasing ideas, HQ may harvest these, decide that the MNC already has its hands full with implementing the ideas, and that the level of delegated discretion may be usefully reduced in order to save costs. Third, HQ may wish to teach what they think are recalcitrant subsidiaries an example. Fourth, HQ may act on (actual or perceived) superior information. This situation might also include that the HQ acts with good intentions but that the assumptions on which the intervention effects are calculated do not hold, for example, because of wrong perceptions or bounded rationality. This is commonly described in the literature on parenting in which it is documented that HQ managers frequently overestimate, for example, synergy potential between subunits which is why they intervene (Goold, \& Campbell, 1998). It also includes situations of Cell III, that is, "objectively" it is entirely warranted that HQ intervenes, and it does so with the best possible intentions. Nevertheless, these intentions are misread and interpreted as demotivating meddling. 


\section{Perceived and Actual HQ Opportunism and Motivation at Subsidiary Level}

Research on organizational behavior suggests that employee motivation can be badly harmed by managerial intervention. Heath, Camerer and Knez (1993) argue that in an employment relationship, employees develop implicit and explicit expectations to the contract governing the relationship, and particularly to the benefits that they believe they deserve under the implicit contract, that is, their "entitlements". Such expectations may be represented by "status quo" points, that is, what employees believe are their entitlements. The discretion that is delegated to employees may become part of their perceived entitlements, and negative motivational consequences follow from managerial intervention that interferes with these entitlements. Other parts of psychological research points to the related phenomenon of loss aversion, that is, a loss relative to a status quo is seen as more undesirable than a gain relative to the same point is seen as desirable (Kahneman, Knetsch \& Thaler, 1991). This means that subsidiaries will develop a bias against reducing their autonomy, and that they can be expected to resist such changes, as well as suffer a loss of motivation if the change is, in fact, forced upon them (Foss, Foss \& Vazquez, 2006).

A substantial body of work in organizational behavior on psychological contracts relates directly to these issues. In the present context, this work suggests that HQ intervention that is perceived of by subsidiaries as being unfair, arbitrary, and in other ways break with what is perceived of as established psychological or implicit contracts (i.e., it is opportunistic) is likely to harm motivation (Rousseau, 1989; Rosseau \& Parks, 1992). ${ }^{10}$ Rousseau and Parks (1992: 36) state that “... contract violation erodes trust [and] undermines the employment relationship yielding lower employee contributions (e.g. performance and attendance) and lower employer investments (e.g., retention, promotion)." In particular, organizational citizenship behavior - that is, employee behavior ("extra-role behavior") that promotes organizational efficiency but is not explicitly recognized by an organization's reward system-may suffer from managerial intervention 
(Robinson \& Morrison, 1995). Empirical work has reached similar conclusions (Robinson, 1996; Foss, 2003; Foss, Foss \& Vazquez, 2006). Finally, research in motivational psychology (i.e., "selfdetermination theory") suggests that individuals have fundamental needs for autonomy, competence, and relations (Deci \& Ryan, 2000; Gagné \& Deci, 2005). Work settings that allow these needs to be fulfilled typically also tap into the autonomous motivation of individuals. Handling certain tasks, notably those related to the exercise of creativity and problem-solving, require this kind of motivation (Amabile, 1996, 1998; Oldham \& Cummings, 1996). External motivators, like the blatant exercise of authority (i.e., intervention), risk harming autonomous motivation because they reduce autonomy and competence.

\section{Consequences of Motivation Losses}

For the MNC, intervention that harms motivation at lower levels in the MNCs is a problem to the extent that loss of motivation leads to managers and employees cutting back on effort (both in their job roles and in their extra-role behaviors), and on firm-specific investments in human and social capital. In particular, extra-role behaviors are likely to suffer. Such behaviors are difficult to measure and directly reward. However, they may be essential to activities such as discovering, creating, sharing and integrating new knowledge within and between MNC units; investing in building and maintaining relations and information channels to other employees or units in the MNC; and supplying the extra intelligent effort that may be required to efficiently cope with changing external contingencies. Notice that these activities are all at the core of the network MNC. Thus, the network MNC may be particularly vulnerable to the kind of HQ intervention that is perceived of as demotivating. We examine this in the following section.

\section{THE NETWORK MNC AND SELECTIVE INTERVENTION HAZARDS}

For the following discussion of HQ intervention we make use of the research model that is depicted in Figure 3. Our key point is that implementing a network MNC has an influence on both 
dimensions of Figure 2: the extent to which HQs intervene, as well as how subsidiaries perceive interventions.

\section{Insert Figure 3 Here}

\section{Intervention in the Network MNC}

Network MNCs are chosen over more hierarchical forms in highly dynamic environments and involve delegating substantial decision autonomy to subsidiaries. Such environments may cause misfit between the organization of the firm and its environment, as new and different contingencies arise. For example, Hedlund (1986) suggests that the hierarchical relationships within network organizations are of a temporary nature, and that they can frequently change direction, that is, decision rights can de facto be transferred to the subsidiary to such an extent that the HQ has very limited influence over the subsidiary. However, this might also go the other way round and HQs might feel the need to intervene. As a consequence, the structuring of the coordination and control system, including the delegation of decision-rights, is at any point in time likely to be imperfect (e.g., Hedlund, 1986; Nickerson \& Zenger, 2005; Piekkari et al., 2010).

The impact of environmental changes in driving HQ intervention is reinforced by the fact that the network MNC is characterized by an often substantial dispersion of knowledge and the HQ decision problems are shrouded in uncertainty (Forsgren \& Holm, 2010). The HQ may suffer from a lack of information about the subsidiary context and the knowledge controlled by the subsidiary. Complemented with bounded rationality and radical uncertainty, such lack of information suggests that the HQ in actuality is unable to perfectly design the organization of the MNC, and especially the delegation of decision-rights, and will have to approximate it through a process of groping. Such groping may be manifest in frequent redesigns of the structure. In sum, the likelihood is high that 
HQs need to or feel the need to intervene on a frequent basis in the network MNC, and more so than in more traditional hierarchical modes of the MNC.

This would be less of a problem if that additional intervention was firmly placed in Cell I (Figure 2), because, although errors would still be made, at least subsidiary motivation would not be harmed. However, much of the additional intervention will take place in Cells II, III and IV. For example, a member of the top-management team may decide to act tough and slash costs in a subsidiary, because this benefits her own career. Because a MNC is in general characterized by strong spatial dispersion and uncertain environments, a manager may get away with this kind of behavior, as tracing costs and managers' behaviors might be a big challenge. For example, the behavior of a regional manager who behaves opportunistically against regional subsidiaries in Asia might be unnoticed by the HQ in Europe, and the costs of this intervention might be misunderstood because of cultural and communication issues. Hence, it may well be that such an opportunistic manager is not punished for his interventions.

Relatedly, HQ managers can be inclined to intervene in subsidiaries because they think that exemplary intervention may show to very powerful subsidiaries "who the boss is". Goold and Campbell (1998) argue that senior managers attribute the right to make decisions and to overrule to their status within the firm, that is, managers might feel redundant in a system which allocates substantial decision rights to lower levels of the firm. Recent literature has shown that subsidiaries can sometimes be very powerful in the sense that they are able to reject HQ orders, influence corporate decisions, and appropriate rents on the subsidiary level which would have created more benefits if the sources of these rents could have been exploited within the whole MNC (Andersson et al. 2007; Mudambi \& Navarra 2004). In such a situation, HQ managers might more likely feel the need to overrule decisions and to intervene in order to strengthen their position vis-à-vis the 
subsidiaries even if this is not to the benefit of the whole corporation. The above reasoning gives rise to the following proposition:

Proposition 1: The more the MNC has implemented a network organization, the higher the frequency of HQ intervention (for good cause and for bad cause).

While MNC network organizations are more prone to intervention overall, intervention that is understood and/or accepted to be for good cause does not lead to motivation problems per se. Yet, chances are that such intervention is perceived as an undue breaking of commitment by the HQ. The reason is that it is difficult to verify the nature of the cause of intervention or that the communication that comes along with the intervention is imperfect. The network MNC has barriers to successful vertical communication (e.g. O'Donnell 2000), for example, because of a lower degree of formalization than in more hierarchical forms. The uncertain and fast-changing environments that the network $\mathrm{MNC}$ is typically located in increase the likelihood that communication of intervention is not synchronized with actual events that lead the intervention in the first place. Finally, powerful subsidiaries might request a lot of very detailed explanations regarding the background of interventions while the complex lateral interdependencies between the units means that no single unit probably has a good overview and understanding of the issues at hand. In sum, this results in misperceptions and, in the worst case, a general bias at the subsidiary level of assuming that any intervention is for a bad cause. In other words:

\section{Proposition 2: The more the MNC has implemented a modern network organization,}

\section{the more likely the subsidiary perceives $\mathrm{HQ}$ intervention as being for bad cause.}

By definition, intervention for good cause is intended to lead to higher MNC performance because it is undertaken only when the HQ manager identifies real net gains from intervening. For example, the HQ might intervene and standardize a product offering across countries because standardization gains across all countries are higher than adaptation gains. Yet, the motivation of 
subsidiaries might still be harmed when intervention for good cause is misperceived by the subsidiary managers. For example, Birkinshaw, Holm, Thilenius, and Arvidsson(2000) have shown that when HQ perceptions and subsidiary perceptions differ, it will eventually have a negative effect on cooperation. We argue that communicating effectively the reasons and needs for good cause intervention is very difficult within the modern network MNC. Hence, we expect that frequent miscommunication and misperceptions influence the relationship between good cause intervention and $\mathrm{MNC}$ performance in a negative way.

By contrast, HQ interventions for bad cause do not produce negative motivational effects in case the subsidiaries do not recognize the true cause of the intervention (Cell II), at least not immediately. This might be the situation when the HQ is able to create a false picture of the intervention and since the MNC context makes it very difficult to verify the nature of the intervention, subsidiaries might believe the HQ managers. However, even if effects on subsidiary motivation is absent, bad cause intervention is negatively related to MNC performance since it is, by definition, an intervention which is not made to realize net gains for the whole MNC. This negative effect is likely to be even stronger when the subsidiaries correctly identify the intervention as being for bad cause. Hence, we formulate the following two propositions:

P3a: The extent to which subsidiaries perceive good cause intervention as for bad cause negatively moderates the positive relationship between good cause intervention and MNC performance.

P3b: The extent to which subsidiaries perceive bad cause intervention as for bad cause negatively moderates the negative relationship between bad cause intervention and MNC performance. 


\section{MANAGEMENT AND ORGANIZATIONAL RESPONSES \\ TO SELECTIVE INTERVENTION HAZARDS}

All firms, MNCs included, face intervention hazards, but we argue that the modern network MNC is particularly prone to such hazards. Hence, the motivation and incentive problems of the modern MNC organization go beyond managing subsidiary moral hazard and opportunism. This is a serious problem given that subsidiary motivation is supposed to be a key driver of network MNCs' performance in the first place (Kim \& Mauborgne, 1991). An important organizational design and management problem therefore concerns keeping intervention hazards at bay. In the following, we discuss three distinct yet interrelated ways to manage these hazards. We link the established issues of "normative integration" and "procedural justice" to the issue of intervention hazards, and we discuss structural remedies.

\section{Normative Integration}

Normative integration has received much emphasis in research on MNC organization (Nohria \& Goshal, 1994). It is argued that common values and beliefs provide harmony of interests and diminish the danger of opportunistic behavior inside the firm, particularly from employees (Ouchi, 1980). Thus, normative integration acts as an implicit contract that instructs organizational members about appropriate behavior and in particular about how to react to new contingencies (cf. Kreps, 1990). In the MNC literature it is featured as an alternative way of how the HQ can "control" the behavior of the subsidiaries. Under normative integration, subsidiary managers are imbued with the values and goals of the MNC and thus act in accordance with them (Ouchi \& Maguire 1975; Edström \& Galbraith 1977). This effectively reduces the need for control by the HQ (Hedlund, 1986).

However, normative integration has to our knowledge exclusively been characterized as a tool available to the HQ to manage its subsidiary network. We argue that normative integration is also 
one way of how intervention hazards can be managed. First, the implementation of a strong organizational culture based on a shared understanding of goals, norms, and beliefs, requires efforts over a relatively long period of time. The success of these efforts is based largely on how consistent and credible the key issues of the culture are communicated as this facilitates their adoption at lower levels. This has the effect that HQ managers themselves identify more with this culture over time; they get socialized as well. Since it is very unlikely that the corporate culture openly features HQ intervention for bad cause, it is very likely that HQ managers investing strongly in corporate culture also refrain from bad cause intervention. In other words, a shared normative context has the effect of enhancing the sense of mutual interdependence between HQ and subsidiary level (Nohria \& Ghoshal, 1994) with HQ opportunism being restrained very much in the same way that subsidiary opportunism is restrained.

\section{P4: MNCs that are high in normative integration will have fewer incidences of intervention for bad cause.}

While HQ managers might refrain from opportunistic intervention under conditions of high normative integration and shared values, it might not be eradicated completely. However, we argue that even if HQ managers sometimes act opportunistically, the effect on subsidiary motivation and consequently on MNC performance might be less severe under conditions of high normative integration than under conditions of a lack of strong organizational culture. This is due to the fact that subsidiary managers simply do not expect the HQ to act opportunistically which in turn influences their perceptions of the interventions positively. Since the verification of the true causes of the intervention is difficult, as are the costs, this might have a strong impact. As long as such interventions occur seldom, subsidiary motivation might not be harmed. Similarly, a strong organizational culture is likely to be based on the promotion of good cause intervention only. This 
improves subsidiary perceptions in general and hence moderates the effect that true good cause intervention has on MNC performance. ${ }^{9}$

P5a: The extent to which the MNC is high in normative integration positively moderates

the negative relationship between intervention for bad cause and MNC performance.

P5b: The extent to which the MNC is high in normative integration positively moderates

the positive relationship between intervention for good cause and MNC performance.

\section{Procedural Justice}

Similarly to the normative integration concept, the concept of procedural justice has been discussed as a tool to control and influence the behavior of subsidiaries as opposed to managing potential opportunism at the HQ-level. It was introduced to the MNC literature mainly by Kim and Mauborgne $(1991 ; 1993 ; 1995)$. Procedural justice can be defined as the perceived fairness of formal procedures governing decisions involving the treatment and benefits of participating partners (Luo 2009). In the context of the MNC, this perceived justice is based on a consistent set of procedures for decision making in which HQ decisions are accompanied with extensive bilateral communication between the HQ and the subsidiaries, and the opportunity for subsidiaries to challenge HQ views (Kim \& Mauborgne, 1991). They argue that the increasingly network-like organization of MNCs decreases the opportunities for HQs to use "hierarchy", that is, fiat, monitoring, and appraisal capability, to make subsidiary managers implement global strategies. This is based on the idea that subsidiary managers in network organizations are the most important "implementers," but that they are likely to have a stronger sense of their own goals and they are often resource-rich and powerful. Hence, in order to be able to successfully implement global strategies, the motivation of the subsidiary managers are required. They conclude that one key element in maintaining such motivation is procedural justice in decision-making processes which

\footnotetext{
${ }^{9}$ We acknowledge that in rare cases the detection of intended bad-cause intervention can have very severe consequences for motivation. This might be because subsidiary managers see the stark contrast between the organizational culture and the bad-cause intervention.
} 
they, in principle, interpret as a driver or a complement of normative integration. Under conditions of high procedural justice, subsidiary managers are motivated to comply with top management decisions even if they are unfavorable for the specific subsidiary, that is, when MNC-wide gains prevailed over subunit optimization.

We argue that procedural justice has two important effects. First, similarly to the effect of normative integration, the extent to which the modern network MNC has implemented a system of procedural justice reduces the likelihood that HQ managers act opportunistically, that is, intervene for bad cause. A system of procedural justice is based on the fact that the HQ is supplying a justification for their behavior and potential interventions as well as accepting challenging and refuting from the subsidiary managers (Kim \& Mauborgne 1991). Hence, it is more likely that opportunistic behavior is detected and finally sanctioned in one way or another. The opportunity to HQ managers to hide their behavior and the effects of their interventions is limited in such a system $^{10}$.

\section{P6: The higher the MNC is in procedural justice, the less frequent is $\mathrm{HQ}$ intervention}

\section{for bad cause.}

Second, a system of procedural justice is the basis for high quality communication in which HQ managers acknowledge the information requirements by subsidiaries, provide the necessary details and reasons, and specifically take into account the potential negative effect on subsidiary motivation in case the HQ decision is perceived as being unfavorable for the subsidiary. Hence, we suggest that a formalized decision system decreases the likelihood that intervention for good cause is misperceived by subsidiary managers.

P7: The higher the MNC is in procedural justice, the less likely that the subsidiary perceives $\mathrm{HQ}$ intervention as being for bad cause.

\footnotetext{
${ }^{10} \mathrm{Kim}$ and Mauborgne (1995) provide some support for the idea that a procedural justice system improves also the content of strategies. This is aligned with our reasoning that bad cause intervention (intended or due to bounded rationality) is less likely to occur.
} 


\section{Structural Mechanisms}

For both normative integration as well as for procedural justice systems we have argued that they constrain primarily HQ intervention for bad cause. Research in political economy suggests that it is often in an organization's long-term interest to avoid later period actions that break promises (with respect to delegation), and that avoiding such behavior may be accomplished by credibly constraining the flexibility of managers in such a manner that the initial promise becomes credible (Kydland \& Prescott, 1977). Normative integration and procedural justice may serve these functions because they commit HQ to certain lines of action and rule others out.

However, in principle, constraining the flexibility of the HQ to selectively intervene in general can also help to reduce harmful selective intervention (not only those that are for bad cause). Since we have argued that especially network-like MNCs are prone to selective intervention (cf. Proposition 1) different organizational forms might remedy the issue of intervention hazards. MNCs struggling with intervention hazards in the network organization could be tempted to alter their organizational form altogether. To this end, Milgrom (1988) argues that employee rent-seeking that aims at influencing hierarchical superiors to selectively intervene to the benefit of the rent-seeking employees will be constrained by rigid, hierarchical structures which makes such rent-seeking more costly. Furthermore, a strong increase in formalized procedures and the implementation of strict rules and policies by definition limits the scope for selective intervention. "(manuals), standing orders, standard operating procedures, etc.” (Ghoshal \& Nohria 1998, p. 335) reduce variance in how decisions are taken, i.e. these mechanisms formally fasten decision rights as well as inputs to decision making on both the HQ as well as the subsidiary level. Hence, this adds to the arguments in favor of more hierarchical structures in MNCs listed by Egelhoff (2010).

Another reason why hierarchical structure may constrain managerial intervention is that the hierarchy is not just a structure of authority, but also one of information (Galbraith, 1973; Egelhoff 
1991). The informational distance between HQ and subsidiaries influences the basis for exercising judgment with respect to decisions whether to overrule lower levels in the MNC or not. All else being equal, the more hierarchical layers that information has to pass through before reaching the exercising authority, the less adequate is this basis likely to be. If the HQ realizes that because of information loss, bounded rationality, and ignorance about subsidiary conditions, it is not in a position to rationally decide whether to selectively intervene or not, it should not intervene (Aghion \& Tirole, 1997). Thus, somewhat paradoxically, the HQ may decide to commit itself by delegating even more decision autonomy to the subsidiaries and by deliberately refraining from gaining certain kind of information (i.e, making itself ignorant).

In sum, firms could be tempted to constrain HQ intervention in general by modifying the organizational form altogether.

P8: The more the network MNCs struggle with keeping intervention hazards at bay the higher the likelihood of a change of organizational form towards either more hierarchical, formalized structures or towards even more strongly decentralized, multidomestic structures.

\section{The Inherent Trade-offs of the Network Model}

Obviously, the structural remedies discussed in Proposition 8 come at high costs. First, there are limits to how far HQ can constrain itself, because a complete hands off strategy may also mean sacrificing the benefits of integrating subsidiaries under the MNC umbrella, i.e. of achieving integration benefits. This could have severe consequences in transnational environments. Second, more hierarchical approaches forego benefits due to flexibility and adaptation.

What emerges is a picture of the network MNC with a number of deep trade-offs that includes also the previously discussed remedies of normative integration and procedural justice. First, 
establishing procedural justice and normative integration may be quite costly in terms of defining basic normative rules, disseminating them, exercising the symbolic management that can maintain and enforce them, etc. This is particularly likely to be the case in MNCs that are very large and dispersed in many different contexts (Egelhoff 1999; Kim \& Mauborgne 1993). The costs of these mechanisms should be balanced against the benefits from reducing motivational loss by constraining selective intervention. This may tilt the trade-off in favor of more traditional structures: A traditional hierarchical structure likely entails lower costs in terms of setting up and running systems for conflict resolution and socializing instruments (Williamson, 1985).

Second, and relatedly, the MNC literature forwards that in a turbulent environment network structures are required to adapt quickly to changing circumstances. An internal justice system might delay decision-making because subsidiary and HQ input has to be heard and evaluated. Such delays could be very costly. Somewhat paradoxically, the need for procedural justice is greater in network organizations, but at the same time, it makes the implementation of procedural justice more difficult (Kim \& Mauborgne 1993).

These trade-offs seem inherent to the network model. Identifying them and the costs and the benefits that give rise to trade-offs, help MNC managers in selecting organizational forms and mechanisms that are least second-best, that is, the best that can be done given the circumstances.

\section{CONCLUDING DISCUSSION}

The strong emphasis of recent MNC literature on the subsidiary-level has implied a certain neglect of HQ activities and rationales (Egelhoff, 2010). What is particularly missing in the current body of literature is a theoretically grounded understanding of how the HQ can manage acts of intervention that it—qua its HQ status—-must perform smoothly, efficiently, and in such a way that little or no harm to subsidiary motivation is caused (unless such harm is overwhelmed by beneficial consequences of the intervention). For example, Hedlund's (1986) notion of multiple, frequently 
changing hierarchies bypasses this question. He does not raise issues related to whether the HQ has the required knowledge and understanding to engage in organization changes, or how such changes might be initiated, motivated, explained, sanctioned, and perceived by lower levels in the MNC network. These issues remain under-researched, in spite of recent attention to HQ ignorance (Forsgren et al., 2005), uncertainty of decision-making (Forsgren \& Holm, 2010), and the political dimensions of MNC network organization (Mudambi \& Navarra, 2004; Andersson et al., 2007). However, even such work still emphasize the power and interests of subsidiaries and does not focus explicitly on the HQ and its role in initiating and managing differentiated and flexible discretion arrangements across the MNC.

We contribute to this gap in a number of ways. By merging relevant work in the fields of international management, economics of the firm, and organizational behavior, we have developed a theoretical framework that links MNC network characteristics to selective intervention hazards (and ultimately MNC performance). Hence, we have suggested a new set of items for research in the function and consequences of the HQ in MNCs. The starting point for our argument is that the HQ is not always benevolent as is routinely assumed in the MNC literature. We argue that the network MNC is subject to more frequent selective HQ intervention, is more prone to suffer from HQ opportunism, and that it is more likely that subsidiaries misperceive even intervention for good cause. In other words, intervention hazards are more rampant in the network MNC. Thus, we argue that the dominant assumption of the MNC literature that corporate HQs are benevolent is a strong assumption, as selective intervention hazard may be substantial.

However, managerial and organizational means exist that can handle intervention hazards. First, we argue that HQ activity can be influenced by normative integration and procedural justice. These mechanisms can help reducing the incidence of bad cause HQ behavior and the risk that lower levels in the MNC mistake good cause intervention for bad cause intervention. This is an 
important contribution to the literature as both mechanisms have exclusively been discussed as a means to manage subsidiaries. We show that these mechanisms might also work "upwards" to manage reverse incentive issues. Hence, both mechanisms might be even more important for network MNCs than usually conceived in large parts of the literature.

Second, both mechanisms suggest important conclusions for the tasks of the HQ and the concept of the differentiated network MNC (Ghoshal \& Nohria, 1989). Normative integration and procedural justice are both mechanisms that require $\mathrm{MNC}$ wide standardization and to some extent also formalization. Yet, the differentiated network MNC is defined as an organization which requires different ways of coordination and control for every single subsidiary (Nohria \& Ghoshal 1997). If normative integration and procedural justice are of such high importance then the HQ's key task is much more about standardizing across the whole MNC than about differentiating its activities according to the subsidiary context. Of course, the outcome of individual decisions can still be adapted to a local subsidiary's context, yet, the HQ's role lies in creating a robust and efficient procedural justice system so that perceptions and intentions of interventions are such that hazards are reduced. Furthermore, we have highlighted a number of crucial trade-offs. By and large, the literature seems to argue that the specific context of network MNCs requires both mechanisms while it creates simultaneously huge constraints on its effective implementation. Thus, it seems to be a particular ability of the MNC to resolve this trade-off - an ability which is arguably located at the HQ-level.

Third, we discuss structural mechanisms to manage intervention hazards. We argue that, paradoxically, one way of keeping intervention hazards under control is either the strong increase of hierarchy in the sense of additional hierarchical layers - or, the near complete abolishment of hierarchy by granting even more discretion to the subsidiaries. This is an important implication, since both mechanisms move, in effect, the MNC structure away from the network MNC. A 
strengthening of the hierarchical structure turns the network MNC more into a formal "global" organization. Rendering even more discretion into the hands of the subsidiaries turns the MNC into a multi-domestic MNC in which benefits from integrating the subsidiaries within the MNC are more strongly neglected. Hence, given the tremendous difficulties firms face when they try to build systems of normative integration and procedural justice, as well as the structural tendencies to remedy network-related intervention hazards with non-network structures, it is not surprising that some researchers suggest that MNC networks are inherently unstable organizations, that they are rarely observed empirically (e.g. Wolf 1997), and that firms might often modulate between organizational structures (Nickerson \& Zenger 2005).

\section{Future Research}

To our knowledge, this paper is the first to be concerned with intervention hazards in MNCs. While we think that this soil is potentially very fertile research-wise, it has basically not been ploughed so far. More research is therefore needed in a number of areas.

First, more conceptual work could be done by adding complexity to our matrix of intervention situations, e.g. by varying the level of knowledge and understanding of HQ (cf. Forsgren \& Holm 2010) that allows them to identify true intervention opportunities. Furthermore, future work could link intervention hazards to the scope of the MNC based on our reasoning that complete hands-off strategies for certain subsidiaries might be effective remedies to intervention hazards while they make it more likely that such a subsidiary does not remain long within the MNC portfolio. Finally, it might be valuable to complement our analysis and to engage into differentiating further the effects of HQ interventions especially in terms of net value creation.

Second, empirical work could validate our key constructs in this paper, notably those of selective intervention for good and bad causes. It could also further propositions that may be distilled from our reasoning. For example, the harmful effects of selective intervention for bad 
cause could be further elaborated. For instance, it may be an empirically open question whether powerful subsidiaries stimulate more or less HQ intervention. One argument (that we have developed here) is that it is more likely that HQ intervene to teach a subsidiary "a lesson" when the subsidiary is strong than when it is less strong. A contrary argument is that HQ will refrain from intervening vis-à-vis powerful subsidiaries that can retaliate in various ways. Note also that our argument is essentially a multi-level one (the relevant variables in our argument are placed on HQ as well as subsidiary levels). Thus, empirical tests of our reasoning should in principle involve multi-level data sampling and the application of multi-level methods.

Theoretically, more research is needed on the set of organizational mechanisms that influence the decision of MNC managers to selectively intervene or not. First, more precise arguments are needed, and perhaps even the kind of formal modeling exercise undertaken by Argyres and Mui (2007) who, like us, are taken up with issues of credible commitment in corporate hierarchies. Second, theorizing is needed to make us better understand what are the relations between different kinds of mechanisms inside hierarchies that handle intervention hazards. For example, are normative integration and procedural justice substitutes or complements for more hierarchical structures with respect to taming intervention hazards? While much needs to be done empirically and theoretically, we are confident that intervention hazards in MNCs is a new exciting angle on internal organization issues in MNCs. 


\section{REFERENCES}

Adler, P. S. \& B. Borys. 1996. Two Types of Bureaucracy: Enabling and Coercive. Administrative Science Quarterly, 41: 61-89.

Aghion, P. \& J.Tirole. 1997. Formal and Real Authority in Organization. Journal of Political Economy 105: 1-29.

Amabile, T. M. 1996. Creativity in Context: Update to the Social Psychology of Creativity. Boulder, CO: Westview.

Amabile, T. M. 1998. How to Kill Creativity. Harvard Business Review, September-October: 7787.

Ambos, B. \& Mahnke, V. 2010. How Do MNC Headquarters Add Value? Management International Review, 50: 403-412.

Anderson, U. \& U. Holm, eds. 2010. Managing the Contemporary Multinational: The Role of HQ. Cheltenham: Edward Elgar.

Andersson, U., Forsgren, M. \& Holm, U. 2007. Balancing Subsidiary Influence in the Federative MNC: A Business Network View. Journal of International Business Studies, 38(5): 802-819.

Argyres, N. \& V.-L. Mui. 2007. Rules of engagement, credibility and the political economy of organizational dissent, Strategic Organization, 5: 107-154.

Asakawa, K. 2001. Evolving HQ-subsidiary Dynamics in International R\&D: The Case of Japanese Multinationals. R\&D Management, 31(1): 1-14.

Baker, G., R. Gibbons \& K.J. Murphy. 1999. Informal Authority in Organizations. Journal of Law, Economics and Organization, 15: 56-73.

Baliga, B.R. \& A. M. Jaeger. 1984. Multinational Corporations: Control Systems and Delegation Issues. Journal of International Business Studies, 15 (2): 25-40.

Barner-Rasmussen, W., Piekkari, R., Scott-Kennel, J., \& Welch, C. 2010. Commander-in-chief or absentee landlord? Key perspectives on HQ in multinational corporations. In Andersson, U. \& Holm, U., eds. Managing the contemporary multinational: The role of $H Q$. Cheltenham: Edward Elgar: 85-105.

Bartlett, C. A. and Ghoshal, S. 1988. Organizing For Worldwide Effectiveness: The Transnational Solution. California Management Review. 31(1): 54. 
Bartlett, C.A. and Ghoshal, S., 1989. Managing across Borders: The Transnational Solution. Harvard Business School Press: Boston, MA.

Benito, G.R.G. \& S. Tomassen. 2010. Governance Costs in HQ-Subsidiary Relationships. in Anderson, U. \& U. Holm, eds. 2010. Managing the Contemporary Multinational: The Role of $H Q$. Cheltenham: Edward Elgar.

Birkinshaw, J. \& T. Pedersen. 2009. Strategy and Management in MNE Subsidiaries. In Alan Rugman (ed.): Oxford Handbook of International Business, second edition, Oxford: Oxford University Press, 367-389

Birkinshaw, J. 1997a. How Multinational Subsidiary Mandates are Gained and Lost. Journal of International Business Studies 27: 467-496

Birkinshaw, J. 1997b. Entrepreneurship in Multinational Corporations: The Characteristics of Subsidiary Initiatives. Strategic Management Journal, 18: 207-229.

Birkinshaw, J.; Holm, U.; Thilenius, P. \& N. Arvidsson (2000): Consequences of perception gaps in the headquarters-subsidiary relationship. International Business Review, 9 (3): 321-345.

Birkinshaw, J. 2001. Entrepreneurship in the Global Firm. Prometheus, 19: 75-92

Birkinshaw, J., Braunerhjelm, P., Holm, U. \& Terjesen, S. 2006. Why Do Some Multinational Corporations Relocate Their HQ Overseas? Strategic Management Journal, 27: 681-700.

Birkinshaw, J.M. \& Hood, N. 1998. Multinational Subsidiary Evolution: Capability and Charter Change in Foreign-Owned Subsidiary Companies. Academy of Management Review, 23(4): 773-795.

Bouquet, C. \& Birkinshaw,J. 2008.Weight vs.voice. How foreign subsidiaries gain attention from corporate headquarters. Academy of Management Journal, 51(3): 577-601.

Brockner, J., T.R. Tyler, Cooper, \& R. Schneider. 1992. The Influence of Prior Commitment to an Institution on Reactions to Perceived Infairness: The Higher They Are, the Harder They Fall, Administrative Science Quarterly, 37: 241-261.

Casson, M. 1994. Why are firms hierarchical? International Journal of the Economics of Business, 1(1): 47-77

Coase, R.H. 1937. The Nature of the Firm. Economica, 4: 386-405.

Cooper, R. \& T.W. Ross. 1985. Product Warranties and Double Moral Hazard. RAND Journal of Economics, 16: 103-113 
Coyle-Shapiro, J. \& I. Kessler. 2000. Consequences of the Psychological Contract for the Employment Relationship: a Large Scale Survey. Journal of Management Studies 37: 903930.

Daniels, J.D., Pitts, R. A. \& Tretter, M.J., 1984. Strategy and Structure of U.S. Multinationals: An Exploratory Study. The Academy of Management Journal, 27: 292-307.

Deci, E. L., \& Ryan, R. M. 2000. The "what" and "why" of goal pursuits: Human needs and the self-determination of behavior. Psychological Inquiry, 11: 227-268.

Dow, G.K., 1987.The function of authority in transaction cost economics. Journal of Economic Behavior \& Organization, 8(1), 13-38.

Doz, Y. \& Prahalad, C. K. 1984. Patterns of Strategic Control Within Multinational Corporations. Journal of International Business Studies 15(2): 55-72.

Doz, Y., Santos, J. F. P., \& Williamson, P. J. 2001. From global to metanational. Boston: Harvard Business School Press.Egelhoff, W.G. 1991. Information-Processing Theory and the Multinational Enterprise. Journal of International Business Studies, 22(3): 341-368.

Egelhoff, W. G. 1991. Information-Processing Theory and the Multinational Enterprise. Journal of International Business Studies, 22 (3): 341-368.

Egelhoff, W.G. 1999. Organizational equilibrium and organizational change: two different perspectives of the multinational enterprise. Journal of International Management, 15 (1), 1533.

Egelhoff, W. G. 2010. How the Parent HQ Adds Value to an MNC. Management International Review, 50: 413-432.

Egelhoff, W.G. \& Wolf, J. 2002. A Reexamination and Extension of International StrategyStructure Theory. Strategic Management Journal, 23(2): 181.

Forsgren, M. 2009. Theories of the Multinational Firm. Cheltenham: Edward Elgar.

Forsgren, M. \& U. Holm. 2010. MNC Headquarters' Role in Subsidiaries' Value-creating Activities: A Problem of Rationality or Radical Uncertainty, Scandinavian Journal of Management, 26: 421-430.

Forsgren, M., U. Holm \& J. Johanson, 2005. Managing the Embedded Multinational. Cheltenham: Edward Elgar.

Foss, K., N.J. Foss \& P. G. Klein. 2007. Original and Derived Judgment: An Entrepreneurial Theory of Economic Organization. Organization Studies, 28: 1893-1912. 
Foss, N. J. 2003. Selective Intervention and Internal Hybrids: Interpreting and Learning from the Rise and Decline of the Oticon Spaghetti Organization, Organization Science 14: 331-349.

Gagné, M. \& E. L. Deci. 2005. Self-Determination Theory and Work Motivation. Journal of Organizational Behavior, 26: 331-362.

Gates, S.R. \& Egelhoff, W.G., 1986. Centralization in HQ-Subsidiary Relationships. Journal of International Business Studies, 17: 71-92.

Ghoshal, S. \& Bartlett, C. A. 1990. The Multinational Corporation as an Interorganizational Network. Academy of Management Review, 15(4): 603-625.

Ghoshal, S. \& Nohria, N. 1989. Internal Differentiation within Multinational Corporations. Strategic Management Journal, 10(4): 323-337.

Ghoshal, S. \& Nohria, N. 1997. The Differentiated MNC: Organizing Multinational Corporation for Value Creation. San Francisco: Jossey-Bass.

Goold, M. \& Campbell, A. 1998. Desperately seeking synergy. Harvard Business Review 76(5): $130-143$.

Greenberg, J. 1990. Looking Fair vs Being Fair: Managing Impressions of Organizational Justice. Reseach in Organizational Behavior 12: 111-157.

Gupta, A.K. \& Govindarajan, V. 2000. Knowledge Flows within Multinational Corporations. Strategic Management Journal, 21(4): 473-396.

Heath, C., M. Knez \& C. Camerer. 1993. The Strategic Management of the Entitlement Process in the Employment Relationship. Strategic Management Journal 14: 75-93.

Hedlund, G. \& Ridderstråle, J. 1996. Toward a Theory of the Self-Renewing MNC. In B. Toyne \& D. Nigh (Eds.), International Business: An Emerging Vision: 329 - 354. Columbia, US: University of South Carolina Press.

Hedlund, G. 1986. The Hyper-Modern MNC-A Heterarchy? Human Resource Management, 25 : 9-35.

Hofstede, G. 1967. The Game of Budget Control. Assen: Van Gorcum \& Co.

Holmström, B. 1999. The firm as a subeconomy. Journal of Law, Economics, and Organization, 15: 74-102.

Jensen, M. C. \& W. H. Meckling. 1992. Specific and General Knowledge and Organizational Structure. In L. Werin and H. Wijkander, eds. 1992. Contract Economics. Oxford: Blackwell. Kahneman, D, Knetsch, J.L. \& Thaler, R.H. 1991. Anomalies: The Endowment Effect, Loss Aversion, and Status Quo Bias. Journal of Economic Perspectives, 5: 193-206. 
Kim, W.C. \& Mauborgne, R.A. 1991. Implementing Global Strategies: The Role of Procedural Justice, Strategic Management Journal, 12, Special Issue, 125-143.

Kim, W.C. \& Mauborgne, R.A. 1993. Procedural Justice, Attitudes, and Subsidiary Top Management Compliance with Multinationals' Corporate Strategic Decisions. The Academy of Management Journal, 36 (3), 502-526.

Kim, W.C. \& Mauborgne, R.A. 1995. A Procedural Justice Model of Strategic Decision Making: Strategy Content Implications in the Multinational, Organization Science, 6 (1), 44-61.

Kouzes, J.M. \& B.Z. Posner. 1993. Credibility: How Leaders Gain and Lose it. San Francisco: Jossey-Bass.

Kreps, D.M., 1990. Corporate Culture and Economic Theory, in: Alt, J. and Shepsle, K. (Eds.), Perspectives on Political Economy. Cambridge University Press: Cambridge, UK.

Kydland, F.E. and E.C. Prescott. 1977. Rules Rather than Discretion: The Inconsistency of Optimal Plans. The Journal of Political Economy, 85: 473-492.

Luo, Y. 2009. Are we on the Same Page? Justice Agreement in International Joint Ventures. Journal of World Business, 44, 383-396.

Malnight, T. 1996. The transition from decentralized to network-based MNC structures: An evolutionary perspective. Journal of International Business Studies, 27(1): 43-66.

Milgrom, P. 1988. Employment Contracts, Influence Activities, and Efficient Organizational Design. Journal of Political Economy 96: 42-60.

Minbaeva,D., Pedersen, T., Björkman,I., Fey, C.F. \& Park H. J. 2003. MNC Knowledge Transfer, Subsidiary Absorptive Capacity, and HRM. Journal of International Business Studies, 34(6): 586.

Mudambi, R. \& Navarra, P. 2004. Is Knowledge Power? Knowledge Flows, Subsidiary Power and Rent-Seeking within MNCs. Journal of International Business Studies, 35(5): 385-406.

Nelson, R.R. \& Winter, S.G., 1982. An Evolutionary Theory of Economic Change. Harvard Univeristy Press: Cambridge, Mass..

Nickerson, J.A. \& T. Zenger. 2005. Being efficiently fickle: A dynamic theory of organizational choice. Organization Science, 13: 547-566.

Nobel, R. \& Birkinshaw, J. 1998. Innovation in Multinational Corporations: Control and Communication Patterns in International R\&D Operations. Strategic Management Journal, 19(5): 479-507. 
Nohria, N. \& Ghoshal, S. 1994. Differentiated Fit and Shared Values: Alternatives for Managing HQ-Subsidiary Relations. Strategic Management Journal, 15(6): 491-502.

Nohria, N. \& Ghoshal, S., 1994. Differentiated fit and shared values: Alternatives for managing HQ-subsidiary relations. Strategic Management Journal, 15: 491-502.

O'Donnell, S. 2000. Managing Foreign Subsidiaries: Agents of HQ, Or an Interdependent Network? Strategic Management Journal, 21(5): 525-548.

Oldham, G. R., \& Cummings, A. 1996. Employee Creativity: Personal and Contextual Factors at Work. Academy of Management Journal, 39: 607-334

Osterloh, M. \& B. Frey. 2000. Motivation, Knowledge Transfer, and Organizational Forms. Organization Science, 11: 538-550.

Parks, J. McLean. 1997. The Fourth Arm of Justice. In B. Lewicki, B. Sheppard, and B. Ries, eds. Research on Negotiation in Organizations, Greenwich, CT: JAI Press: 113-144.

Perlmutter, H. V. 1969. The tortuous evolution of the multinational corporation. Columbia Journal of World Business, January-February: 8-18.

Piekkari, R., Nell, P.C. \& Ghauri, P. 2010. Regional Management as a System - A Longitudinal Study. Management International Review, 50: 513-532.

Prahalad, C.K. \& Doz, Y.L., 1987. The multinational mission: Balancing local demands and global vision. New York: The Free Press.

Robinson, S. L. 1996. Trust and Breach of the Psychological Contract. Administrative Science Quarterly 41: 574-599.

Robinson, S.L. \& E. Wolfe Morrison. 1995. Psychological Contracts and OCB: The Effects of Unfulfilled Obligations on Civic Virtue Behavior. Journal of Organizational Behavior 16: 289-298.

Robinson, Sandra L. and Denise M. Rousseau. 1994. Violating the Psychological Contract: Not the Exception but the Norm. Journal of Organizational Behavior 15: 245-259.

Rousseau, D. M. \& Parks, J. M. The contracts of individuals and organizations. In L. L. Cummings and B. M. Staw (Eds.), Research in Organizational Behavior, 1993, Volume 15, pp. 1-43. Greenwich,CT: JAI Press.

Rousseau, D. M. 1989. Psychological and Implied Contracts in Organizations. Employee Responsibilities and Rights Journal, 8: 121-139.

Simon, H.A. 1951. A Formal Theory of the Employment Relationship. Econometrica, 19: 293-305. 
Simon, H.A. 1991. Organizations and Markets. Journal of Economic Perspectives, 5(2): 28.

Stopford, J.M. \& Wells, L.T. Jr., 1972. Managing the Multinational Enterprise, Basic Book.

Tallman, S. \& Koza, M. P. 2010. Keeping the Global in Mind - The Evolution of the HQ' Role in Global Multi-business Firms. Management International Review.

Tyler, Tom R. \& Steven Blader. 2000. Cooperation in Groups: Procedural Justice, Social Identity, and Behavioral Engagement. Psychology Press.

Van de Ven, A. H. \& Delbecq, A. L. 1976. Determinants of Coordination Modes Within Organizations. American Sociological Review. 41: 322-338.

Van de Ven, A.H. \& R. Drazin. 1985. The Concept of Fit in Contingency Theory. Research in Organizational Behavior 7: 333-365.

Verbeke, A. \& N.S. Greidanus. 2009. The End of the Opportunism vs Trust Debate: Bounded Reliability as a New Envelope Concept in Research on MNE Governance. Journal of International Business Studies, 40: 1471-1495.

Williamson, O. E. 1993. Transaction Cost Economics Meets Posnerian Law and Economics. Journal of Institutional and Theoretical Economics 149: 99-118.

Williamson, O.E. 1985. The Economic Institutions of Capitalism. New York: Free Press.

Williamson, O.E., 1991. Comparative Economic Organization: The Analysis of Discrete Structural Alternatives. Administrative Science Quarterly, 36(2), 269-296.

Williamson, O. E. 1996. The Mechanisms of Governance. Oxford: Oxford University Press.

Wolf, J. 1997. From "Starworks" to networks and heterachies? Theoretical rationale and empirical evidence of HRM organization in MNC. Management International Review, 37: 145-169.

Zenger, T. \& W. Hesterly. 1997. The Disaggregation of Corporations: Selective Intervention, HighPowered Incentives, and Molecular Units. Organization Science, 8: 209-222. 
Figure 1: Overall Research Framework

\begin{tabular}{|c|c|c|c|}
\hline $\begin{array}{l}\text { MNC Network } \\
\text { Characteristics }\end{array}$ & $\begin{array}{l}\text { Center } \\
\text { Intervention }\end{array}$ & $\begin{array}{l}\text { Sub-unit } \\
\text { Motivation }\end{array}$ & $\begin{array}{l}\text { Performance } \\
\text { Outcomes }\end{array}$ \\
\hline $\begin{array}{l}\text { (The MNC } \\
\text { literature in IB) }\end{array}$ & $\begin{array}{l}\text { (The theory of the } \\
\text { firm literature) }\end{array}$ & $\begin{array}{l}\text { (The organizational } \\
\text { behavior literature) }\end{array}$ & \\
\hline
\end{tabular}

Figure 2: Typology of HQ Interventions and Their Perceptions

\begin{tabular}{|c|c|c|c|}
\hline \multirow{3}{*}{$\begin{array}{l}\text { Subsidiary } \\
\text { Perception of } \\
\text { HQ } \\
\text { Intervention }\end{array}$} & $\begin{array}{l}\text { For Good } \\
\text { Cause }\end{array}$ & $\begin{array}{l}\text { I } \\
\text { Dominant Assumption } \\
\text { in International } \\
\text { Management Literature }\end{array}$ & II \\
\hline & $\begin{array}{c}\text { For } \\
\text { BadCause }\end{array}$ & III & IV \\
\hline & & $\begin{array}{l}\text { For Good } \\
\text { Cause }\end{array}$ & $\begin{array}{c}\text { For Bad } \\
\text { Cause }\end{array}$ \\
\hline Selective & ervention & azards & \\
\hline
\end{tabular}


Figure 3: Key Constructs and Their Relationships

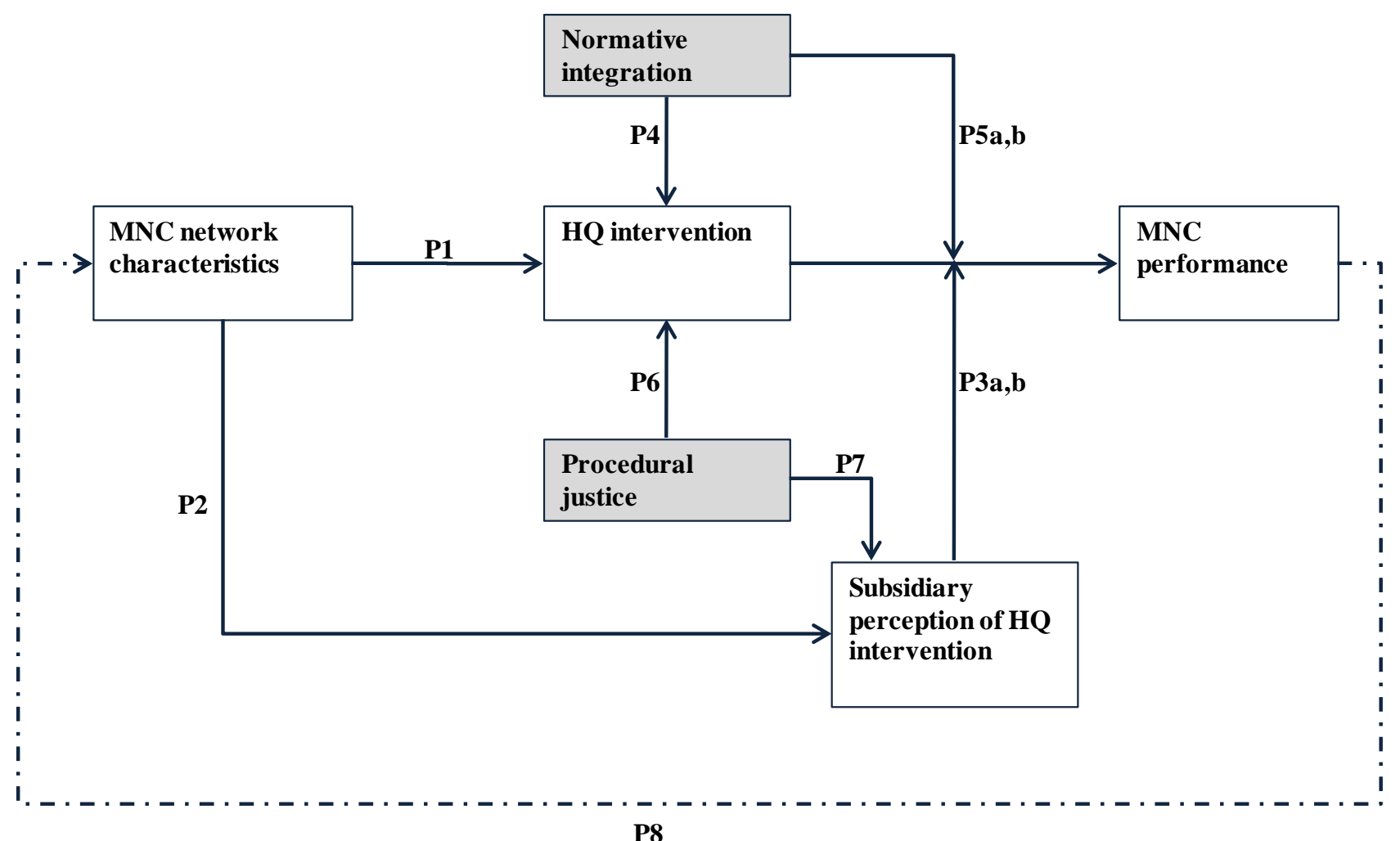




\section{SMG - Working Papers \\ www.cbs.dk/smg \\ 2003}

2003-1: Nicolai J. Foss, Kenneth Husted, Snejina Michailova, and Torben Pedersen: Governing Knowledge Processes: Theoretical Foundations and Research Opportunities.

2003-2: Yves Doz, Nicolai J. Foss, Stefanie Lenway, Marjorie Lyles, Silvia Massini, Thomas P. Murtha and Torben Pedersen: Future Frontiers in International Management Research: Innovation, Knowledge Creation, and Change in Multinational Companies.

2003-3: Snejina Michailova and Kate Hutchings: The Impact of In-Groups and OutGroups on Knowledge Sharing in Russia and China CKG Working Paper.

2003-4: Nicolai J. Foss and Torben Pedersen: The MNC as a Knowledge Structure: The Roles of Knowledge Sources and Organizational Instruments in MNC Knowledge Management CKG Working Paper.

2003-5: Kirsten Foss, Nicolai J. Foss and Xosé H. Vázquez-Vicente: “Tying the Manager's Hands": How Firms Can Make Credible Commitments That Make Opportunistic Managerial Intervention Less Likely CKG Working Paper.

2003-6: Marjorie Lyles, Torben Pedersen and Bent Petersen: Knowledge Gaps: The Case of Knowledge about Foreign Entry.

2003-7: Kirsten Foss and Nicolai J. Foss: The Limits to Designed Orders: Authority under "Distributed Knowledge" CKG Working Paper.

2003-8: Jens Gammelgaard and Torben Pedersen: Internal versus External Knowledge Sourcing of Subsidiaries - An Organizational Trade-Off.

2003-9: Kate Hutchings and Snejina Michailova: Facilitating Knowledge Sharing in Russian and Chinese Subsidiaries: The Importance of Groups and Personal Networks Accepted for publication in Journal of Knowledge Management.

2003-10: Volker Mahnke, Torben Pedersen and Markus Verzin: The Impact of Knowledge Management on MNC Subsidiary Performance: the Role of Absorptive Capacity CKG Working Paper.

2003-11: Tomas Hellström and Kenneth Husted: Mapping Knowledge and Intellectual Capital in Academic Environments: A Focus Group Study Accepted for publication in Journal of Intellectual Capital CKG Working Paper.

2003-12: Nicolai J Foss: Cognition and Motivation in the Theory of the Firm: Interaction or "Never the Twain Shall Meet"? Accepted for publication in Journal des Economistes et des Etudes Humaines CKG Working Paper.

2003-13: Dana Minbaeva and Snejina Michailova: Knowledge Transfer and Expatriation Practices in MNCs: The Role of Disseminative Capacity.

2003-14: Christian Vintergaard and Kenneth Husted: Enhancing Selective Capacity Through Venture Bases. 


\section{4}

2004-1: Nicolai J. Foss: Knowledge and Organization in the Theory of the Multinational Corporation: Some Foundational Issues

2004-2: Dana B. Minbaeva: HRM Practices and MNC Knowledge Transfer

2004-3: Bo Bernhard Nielsen and Snejina Michailova: Toward a Phase-Model of Global Knowledge Management Systems in Multinational Corporations

2004-4: Kirsten Foss \& Nicolai J Foss: The Next Step in the Evolution of the RBV: Integration with Transaction Cost Economics

2004-5: Teppo Felin \& Nicolai J. Foss: Methodological Individualism and the Organizational Capabilities Approach

2004-6: Jens Gammelgaard, Kenneth Husted, Snejina Michailova: Knowledge-sharing Behavior and Post-acquisition Integration Failure

2004-7: Jens Gammelgaard: Multinational Exploration of Acquired R\&D Activities

2004-8: Christoph Dörrenbächer \& Jens Gammelgaard: Subsidiary Upgrading? Strategic Inertia in the Development of German-owned Subsidiaries in Hungary

2004-9: Kirsten Foss \& Nicolai J. Foss: Resources and Transaction Costs: How the Economics of Property Rights Furthers the Resource-based View

2004-10: Jens Gammelgaard \& Thomas Ritter: The Knowledge Retrieval Matrix: Codification and Personification as Separate Strategies

2004-11: Nicolai J. Foss \& Peter G. Klein: Entrepreneurship and the Economic Theory of the Firm: Any Gains from Trade?

2004-12: Akshey Gupta \& Snejina Michailova: Knowledge Sharing in Knowledge-Intensive Firms: Opportunities and Limitations of Knowledge Codification

2004-13: Snejina Michailova \& Kate Hutchings: Knowledge Sharing and National Culture: A Comparison Between China and Russia

\section{5}

2005-1: Keld Laursen \& Ammon Salter: My Precious - The Role of Appropriability Strategies in Shaping Innovative Performance

2005-2: Nicolai J. Foss \& Peter G. Klein: The Theory of the Firm and Its Critics: A Stocktaking and Assessment

2005-3: Lars Bo Jeppesen \& Lars Frederiksen: Why Firm-Established User Communities Work for Innovation: The Personal Attributes of Innovative Users in the Case of Computer-Controlled Music

2005-4: Dana B. Minbaeva: Negative Impact of HRM Complementarity on Knowledge Transfer in MNCs

2005-5: Kirsten Foss, Nicolai J. Foss, Peter G. Klein \& Sandra K. Klein: Austrian Capital 
Theory and the Link Between Entrepreneurship and the Theory of the Firm

2005-1: Nicolai J. Foss: The Knowledge Governance Approach

2005-2: Torben J. Andersen: Capital Structure, Environmental Dynamism, Innovation Strategy, and Strategic Risk Management

2005-3: Torben J. Andersen: A Strategic Risk Management Framework for Multinational Enterprise

2005-4: Peter Holdt Christensen: Facilitating Knowledge Sharing: A Conceptual Framework

2005-5 Kirsten Foss \& Nicolai J. Foss: Hands Off! How Organizational Design Can Make Delegation Credible

2005-6 Marjorie A. Lyles, Torben Pedersen \& Bent Petersen: Closing the Knowledge Gap in Foreign Markets - A Learning Perspective

2005-7 Christian Geisler Asmussen, Torben Pedersen \& Bent Petersen: How do we Capture "Global Specialization" when Measuring Firms' Degree of internationalization?

2005-8 Kirsten Foss \& Nicolai J. Foss: Simon on Problem-Solving: Implications for New Organizational Forms

2005-9 Birgitte Grøgaard, Carmine Gioia \& Gabriel R.G. Benito: An Empirical Investigation of the Role of Industry Factors in the Internationalization Patterns of Firms

2005-10 Torben J. Andersen: The Performance and Risk Management Implications of Multinationality: An Industry Perspective

2005-11 Nicolai J. Foss: The Scientific Progress in Strategic Management: The case of the Resource-based view

2005-12 Koen H. Heimeriks: Alliance Capability as a Mediator Between Experience and Alliance Performance: An Empirical Investigation Into the Alliance Capability Development Process

2005-13 Koen H. Heimeriks, Geert Duysters \& Wim Vanhaverbeke: Developing Alliance Capabilities: An Empirical Study

2005-14 JC Spender: Management, Rational or Creative? A Knowledge-Based Discussion

\section{6}

2006-1: Nicolai J. Foss \& Peter G. Klein: The Emergence of the Modern Theory of the Firm

2006-2: Teppo Felin \& Nicolai J. Foss: Individuals and Organizations: Thoughts on a Micro-Foundations Project for Strategic Management and Organizational Analysis

2006-3: Volker Mahnke, Torben Pedersen \& Markus Venzin: Does Knowledge Sharing 
Pay? An MNC Subsidiary Perspective on Knowledge Outflows

2006-4: Torben Pedersen: Determining Factors of Subsidiary Development

2006-5 Ibuki Ishikawa: The Source of Competitive Advantage and Entrepreneurial Judgment in the RBV: Insights from the Austrian School Perspective

2006-6 Nicolai J. Foss \& Ibuki Ishikawa: Towards a Dynamic Resource-Based View: Insights from Austrian Capital and Entrepreneurship Theory

2006-7 Kirsten Foss \& Nicolai J. Foss: Entrepreneurship, Transaction Costs, and Resource Attributes

2006-8 Kirsten Foss, Nicolai J. Foss \& Peter G. Klein: Original and Derived Judgement: An Entrepreneurial Theory of Economic Organization

2006-9 Mia Reinholt: No More Polarization, Please! Towards a More Nuanced Perspective on Motivation in Organizations

2006-10 Angelika Lindstrand, Sara Melen \& Emilia Rovira: Turning social capital into business? A study of Swedish biotech firms' international expansion

2006-11 Christian Geisler Asmussen, Torben Pedersen \& Charles Dhanaraj: Evolution of Subsidiary Competences: Extending the Diamond Network Model

2006-12 John Holt, William R. Purcell, Sidney J. Gray \& Torben Pedersen: Decision Factors Influencing MNEs Regional Headquarters Location Selection Strategies

2006-13 Peter Maskell, Torben Pedersen, Bent Petersen \& Jens Dick-Nielsen: Learning Paths to Offshore Outsourcing - From Cost Reduction to Knowledge Seeking

2006-14 Christian Geisler Asmussen: Local, Regional or Global? Quantifying MNC Geographic Scope

2006-15 Christian Bjørnskov \& Nicolai J. Foss: Economic Freedom and Entrepreneurial Activity: Some Cross-Country Evidence

2006-16 Nicolai J. Foss \& Giampaolo Garzarelli: Institutions as Knowledge Capital: Ludwig M. Lachmann's Interpretative Institutionalism

2006-17 Koen H. Heimriks \& Jeffrey J. Reuer: How to Build Alliance Capabilities

2006-18 Nicolai J. Foss, Peter G. Klein, Yasemin Y. Kor \& Joseph T. Mahoney: Entrepreneurship, Subjectivism, and the Resource - Based View: Towards a New Synthesis

2006-19 Steven Globerman \& Bo B. Nielsen: Equity Versus Non-Equity International Strategic Alliances: The Role of Host Country Governance

\section{7}

2007-1 Peter Abell, Teppo Felin \& Nicolai J. Foss: Building Micro-Foundations for the Routines, Capabilities, and Performance Links 
2007-2 Michael W. Hansen, Torben Pedersen \& Bent Petersen: MNC Strategies and Linkage Effects in Developing Countries

2007-3 Niron Hashai, Christian G. Asmussen, Gabriel R.G. Benito \& Bent Petersen: Predicting the Diversity of Foreign Entry Modes

2007-4 Peter D. Ørberg Jensen \& Torben Pedersen: Whether and What to Offshore?

2007-5 Ram Mudambi \& Torben Pedersen: Agency Theory and Resource Dependency Theory: Complementary Explanations for Subsidiary Power in Multinational Corporations

2007-6 Nicolai J. Foss: Strategic Belief Management

2007-7 Nicolai J. Foss: Theory of Science Perspectives on Strategic Management Research: Debates and a Novel View

2007-8 Dana B. Minbaeva: HRM Practices and Knowledge Transfer in MNCs

2007-9 Nicolai J. Foss: Knowledge Governance in a Dynamic Global Context: The Center for Strategic Management and Globalization at the Copenhagen Business School

2007-10 Paola Gritti \& Nicolai J. Foss: Customer Satisfaction and Competencies: An Econometric Study of an Italian Bank

2007-11 Nicolai J. Foss \& Peter G. Klein: Organizational Governance

2007-12 Torben Juul Andersen \& Bo Bernhard Nielsen: The Effective Ambidextrous Organization: A Model of Integrative Strategy Making Processes.

\section{8}

2008-1 Kirsten Foss \& Nicolai J. Foss: Managerial Authority When Knowledge is Distributed: A Knowledge Governance Perspective

2008-2 Nicolai J. Foss: Human Capital and Transaction Cost Economics.

2008-3 Nicolai J. Foss \& Peter G. Klein: Entrepreneurship and Heterogeneous Capital.

2008-4 Nicolai J. Foss \& Peter G. Klein: The Need for an Entrepreneurial Theory of the Firm.

2008-5 Nicolai J. Foss \& Peter G. Klein: Entrepreneurship: From Opportunity Discovery to Judgment.

2008-6 Mie Harder: How do Rewards and Management Styles Influence the Motivation to Share Knowledge?

2008-7 Bent Petersen, Lawrence S. Welch \& Gabriel R.G. Benito: Managing the Internalisation Process - A Theoretical Perspective.

2008-8 Torben Juul Andersen: Multinational Performance and Risk Management Effects: Capital Structure Contingencies. 
2008-9 Bo Bernard Nielsen: Strategic Fit and the Role of Contractual and Procedural Governance in Alliances: A Dynamic Perspective.

2008-10 Line Gry Knudsen \& Bo Bernhard Nielsen: Collaborative Capability in R\&D Alliances: Exploring the Link between Organizational and Individual level Factors.

2008-11 Torben Juul Andersen \& Mahesh P. Joshi: Strategic Orientations of Internationalizing Firms: A Comparative Analysis of Firms Operating in Technology Intensive and Common Goods Industries.

2008-12 Dana Minbaeva: HRM Practices Affecting Extrinsic and Intrinsic Motivation of Knowledge Receivers and their Effect on Intra-MNC Knowledge Transfer.

2008-13 Steen E. Navrbjerg \& Dana Minbaeva: HRM and IR in Multinational Corporations: Uneasy Bedfellows?

2008-14 Kirsten Foss \& Nicolai J. Foss: Hayekian Knowledge Problems in Organizational Theory.

2008-15 Torben Juul Andersen: Multinational Performance Relationships and Industry Context.

2008-16 Larissa Rabbiosi: The Impact of Subsidiary Autonomy on MNE Knowledge Transfer: Resolving the Debate.

2008-17 Line Gry Knudsen \& Bo Bernhard Nielsen: Organizational and Individual Level Antecedents of Procedural Governance in Knowledge Sharing Alliances.

2008-18 Kirsten Foss \& Nicolai J. Foss: Understanding Opportunity Discovery and Sustainable Advantage: The Role of Transaction Costs and Property Rights.

2008-19 Teppo Felin \& Nicolai J. Foss: Social Reality, The Boundaries of Self-fulfilling Prophecy, and Economics.

2008-20 Yves Dos, Nicolai J. Foss \& José Santos: A Knowledge System Approach to the Multinational Company: Conceptual Grounding and Implications for Research

2008-21 Sabina Nielsen \& Bo Bernhard Nielsen: Why do Firms Employ foreigners on Their Top Management Teams? A Multi-Level Exploration of Individual and Firm Level Antecedents

2008-22 Nicolai J. Foss: Review of Anders Christian Hansen's “Uden for hovedstrømmen - Alternative strømninger i økonomisk teori"

2008-23 Nicolai J. Foss: Knowledge, Economic Organization, and Property Rights

2008-24 Sjoerd Beugelsdijk, Torben Pedersen \& Bent Petersen: Is There a Trend Towards Global Value Chain Specialization? - An Examination of Cross Border Sales of US Foreign Affiliates 
2008-25 Vikas Kumar, Torben Pedersen \& Alessandro Zattoni: The performance of business group firms during institutional transition: A longtitudinal study of Indian firms

2008-26 Sabina Nielsen \& Bo B. Nielsen: The effects of TMT and Board Nationality Diversity and Compensation on Firm Performance

2008-27 Bo B. Nielsen \& Sabina Nielsen: International Diversification Strategy and Firm Performance: A Multi-Level Analysis of Firm and Home Country Effects

\section{9}

2009-1 Nicolai J. Foss: Alternative Research Strategies in the Knowledge Movement: From Macro Bias to Micro-Foundations and Multi-Level Explanation

2009-2 Nicolai J. Foss \& Peter G. Klein: Entrepreneurial Alertness and Opportunity Discovery: Origins, Attributes, Critique

2009-3 Nicolai J. Foss \& Dana B. Minbaeva: Governing Knowledge: The Strategic Human Resource Management Dimension

2009-4 Nils Stieglitz \& Nicolai J. Foss: Opportunities and New Business Models: Transaction Cost and Property Rights Perspectives on Entrepreneurships

2009-5 Torben Pedersen: Vestas Wind Systems A/S: Exploiting Global R\&D Synergies

2009-6 Rajshree Agarwal, Jay B. Barney, Nicolai J. Foss \& Peter G. Klein: Heterogeneous Resources and the Financial Crisis: Implications of Strategic Management Theory

2009-7 Jasper J. Hotho: A Measure of Comparative Institutional Distance

2009-8 Bo B. Nielsen \& Sabina Nielsen: The Impact of Top Management Team Nationality Diversity and International Experience on Foreign Entry Mode

2009-9 Teppo Felin \& Nicolai Juul Foss: Experience and Repetition as Antecedents of Organizational Routines and Capabilities: A Critique of Behaviorist and Empiricist Approaches

2009-10 Henk W. Volberda, Nicolai J. Foss \& Marjorie E. Lyles: Absorbing the Concept of Absorptive Capacity: How To Realize Its Potential in the Organization Field

2009-11 Jan Stentoft Arlbjørn, Brian Vejrum Wæhrens, John Johansen \& Torben Pedersen: Produktion i Danmark eller offshoring/outsourcing: Ledelsesmæssige udfordringer 


\section{0}

2010-1 Dana B. Minbaeva, Kristiina Mäkelä \& Larissa Rabbiosi: Explaining Intraorganizational Knowledge Transfer at the Individual Level

2010-2 Dana B.Minbaeva \& Torben Pedersen: Governing Individual Knowledge Sharing Behavior

2010-3 Nicolai J. Foss \& Peter G. Klein: Alertness, Judgment, and the Antecedents of Entrepreneurship

2010-4 Nicolai J.Foss \& Joseph T.Mahoney: Exploring Knowledge Governance

2010-5 Jasper J. Hotho, Florian Becker-Ritterspach \& Ayse Saka-Helmhout: Enriching Absorptive Capacity Through Social Interaction

2010-6 Nicolai J. Foss \& Bo B. Nielsen: Researching Collaborative Advantage: Some Conceptual and Multi-level Issues

2010-7 Nicolai J. Foss \& Nils Stieglitz: Modern Resource-Based Theory(ies)

2010-8 Christian Bjørnskov \& Nicolai J. Foss: Do Economic Freedom and Entrepreneurship Impact Total Factor Productivity?

2010-9 Gabriel R.G. Benito, Bent Petersen \& Lawrence S. Welch: Mode Combinations and International Operations: Theoretical Issues and an Empirical Investigation

\section{1}

2011-1 Peter D. Ørberg Jensen \& Bent Petersen: Human Asset Internalization and Global Sourcing of Services - A Strategic Management Analysis on Activity-level

2011-2 Mie Harder: Management Innovation Capabilities: A Typology and Propositions for Management Innovation Research

2011-3 Mie Harder: Internal Antecedents of Management Innovation: The effect of diagnostic capability and implementation capability 
2011-4 Mie Harder: Explaining Management Innovation Pervasiveness: The Role of Internal Antecedents

2011-5 Mie Harder: Internal Determinants of Product Innovation and Management Innovation: The Effect of Diagnostic Capability and Implementation Capability

2011-6 Nicolai J. Foss, Peter G. Klein \& Per L. Bylund: Entrepreneurship and the Economics of the Firm

2011-7 Nicolai J. Foss \& Jacob Lyngsie: The Emerging Strategic Entrepreneurship Field: Origins, Key Tenets and Research Gaps

2011-8 Nicolai J. Foss: Entrepreneurship in the Context of the Resource-based View of the Firm

2011-9 Bent Petersen, Gabriel R.G. Benito, Olesya Dovgan \& Lawrence Welch: Offshore outsourcing: A dynamic, operation mode perspective

2011-10 Bent Petersen, Gabriel R. G. Benito \& Lawrence Welch: Dynamics of Foreign Operation Modes and their Combinations: Insights for International Strategic Management

2011-11 Nicolai J. Foss: Teams, Team Motivation, and the Theory of the Firm

2011-12 Nicolai J. Foss: Knowledge Governance: Meaning, Nature, Origins, and Implications

2011-13 Nicolai J. Foss, Kirsten Foss \& Phillip C. Nell: MNC Organizational Form and Subsidiary Motivation Problems: Controlling Intervention Hazards in the Network MNC 
